\title{
Tracking dynamics of plant biomass composting by changes in substrate structure, microbial community, and enzyme activity
}

\author{
Hui Wei ${ }^{1 *}$, Melvin P Tucker ${ }^{2}$, John O Baker ${ }^{1}$, Michelle Harris ${ }^{1}$, Yonghua Luo ${ }^{1}$, Qi Xu', Michael E Himmel ${ }^{1}$ and \\ Shi-You Ding ${ }^{1 *}$
}

\begin{abstract}
Background: Understanding the dynamics of the microbial communities that, along with their secreted enzymes, are involved in the natural process of biomass composting may hold the key to breaking the major bottleneck in biomass-to-biofuels conversion technology, which is the still-costly deconstruction of polymeric biomass carbohydrates to fermentable sugars.

However, the complexity of both the structure of plant biomass and its counterpart microbial degradation communities makes it difficult to investigate the composting process.
\end{abstract}

Results: In this study, a composter was set up with a mix of yellow poplar (Liriodendron tulipifera) wood-chips and mown lawn grass clippings (85:15 in dry-weight) and used as a model system. The microbial rDNA abundance data obtained from analyzing weekly-withdrawn composted samples suggested population-shifts from bacteriadominated to fungus-dominated communities. Further analyses by an array of optical microscopic, transcriptional and enzyme-activity techniques yielded correlated results, suggesting that such population shifts occurred along with early removal of hemicellulose followed by attack on the consequently uncovered cellulose as the composting progressed.

Conclusion: The observed shifts in dominance by representative microbial groups, along with the observed different patterns in the gene expression and enzymatic activities between cellulases, hemicellulases, and ligninases during the composting process, provide new perspectives for biomass-derived biotechnology such as consolidated bioprocessing (CBP) and solid-state fermentation for the production of cellulolytic enzymes and biofuels.

Keywords: Compost, Plant biomass, Yellow poplar, Microbial community, Microbial rDNA abundance, Gene expression, Enzymatic activity, Cellulase, Hemicellulose, Ligninase, Consolidated bioprocessing (CBP), Solid-state fermentation, Biofuels

\section{Background}

The intertwining matrix of biopolymers (celluloses, hemicelluloses, and lignins, as prominent examples) of which plant cell walls are composed poses a major obstacle to the deconstruction of these walls to simple sugars and chemicals that can serve as raw materials for the fermentative production of alternative liquid fuels and other bioproducts. This major bottleneck in

\footnotetext{
* Correspondence: Hui.Wei@nrel.gov; Shi.you.Ding@nrel.gov 'Biosciences Center, National Renewable Energy Laboratory, Golden, CO 80401, USA

Full list of author information is available at the end of the article
}

biomass conversion technology can be mitigated by 1 ) reducing plant biomass recalcitrance through genetic engineering of energy crops, thereby 2) minimizing the requirement for thermo-chemical feedstock pretreatment, 3) improving performance of the enzymes used for saccharification, and 4) introducing the one step conversion concept, or consolidated bioprocessing (CBP), in which enzyme production, enzymatic hydrolysis, and fermentation are combined for microbial production of biofuels using biomass as substrates [1].

Traditionally, composting is defined as a process that heaps together organic materials (notably food waste,
C Biomed Central

() 2012 Wei et al; licensee BioMed Central Ltd. This is an Open Access article distributed under the terms of the Creative Commons Attribution License (http://creativecommons.org/licenses/by/2.0), which permits unrestricted use, distribution, and reproduction in any medium, provided the original work is properly cited. 
manure, plant leaves and stems, grass trimmings, crop residues, paper, and wood, etc.), and allows them to decay enough to be ready either for use as soil enhancers or for disposal. This composting process mainly depends on microorganisms (including archaea, bacteria and fungi) to break down the organic materials. In the past decades, composting has evolved from a means for the management of agricultural and residential waste $[2,3]$, or for their conversion of into value-added products such as fertilizers [4,5] to a tool used to mine for novel microorganisms and enzymes to be applied to the conversion of plant biomass to biofuels [6,7].

The advantages provided by the study of composting systems (vs. study of other ecosystems such as soils and wood/leaf litters) include: 1) allowing more control over the exo-environmental conditions, such as external temperature, moisture, etc., and 2) generation of a more diverse microbial community because of the steeply decreasing oxygen gradient from outermost to innermost layers of a compost pile [8]. These advantages make composting studies a rich area to be mined for activities useful in both biological pretreatment of biomass feedstocks and in the ultimate saccharification step.

It is a generally accepted idea that environments and cell-cell interactions shape the species composition in communities [9-11]. In addition, numerous published reports have revealed that the diversity of microbial communities and their secreted enzymes that are involved in degradation is correlated with biomass type (different tissue types or plant species) [see review [8]], which suggests that composting of a recalcitrant lignocellulose-based biomaterial is more likely to lead to a microbial community with higher capacity in degrading plant cell walls, when compared to composting of other more readily degraded materials such as kitchen food wastes. From this perspective, the fact that the biomass of woody energy crops (such as yellow poplar) has significantly higher recalcitrance indices (with values of 0.56-0.87) than those of herbaceous energy crops $(0.25$ 0.45 ; [8]), suggests that knowledge derived from yellow poplar-composting can be directly and effectively applied to the conversion of woody plant biomass to simple sugars.

Most previous studies of composting have mainly focused on characterizing the microbial composition of the composting communities [3,12-14], with only a few focused on the morphological changes in the surface structure of plant biomass substrates [15], and even fewer on the characterization of the cellulolytic enzymes and their encoding genes, let alone the correlations between the above multiple aspects of composting. Recent metagenomic studies of soils and biomass composts $[6,9,16]$ have yielded significant insights into uncultivated microbial communities; these studies, however, have investigated only single or a few sampling time points, probably due to the considerable cost and labor-intensity of analyzing the metagenomic data.

The major objectives of the current study were to fill the above voids by conducting, for the first time, a timeline characterization of the yellow poplar woodchip-based biomass decay community. We hypothesize that, in the biomass composting ecosystem, the microbial community involved in the deconstruction process of biomass is dynamically correlated with the status of biomass substrates, as well as with environmental and timing factors. To test this hypothesis, comprehensive, multi-directional approaches are employed herein to draw time-course correlations between the microbial composition, functional gene expression, cellulolytic enzyme activity, and plant cell wall structural changes.

\section{Results}

As described in the Materials and Methods section, the composting bin (Figure 1) was set up indoors, and temperature and oxygen levels in the composting mass were regularly monitored. Figure $1 \mathrm{C}$ shows a typical compost pattern [3] with three stages. Initially a mesophilic phase I $\left(20^{\circ}-50^{\circ} \mathrm{C}\right)$ of 6 weeks was observed, followed by a brief thermophilic phase (one week above $50^{\circ} \mathrm{C}$ ).
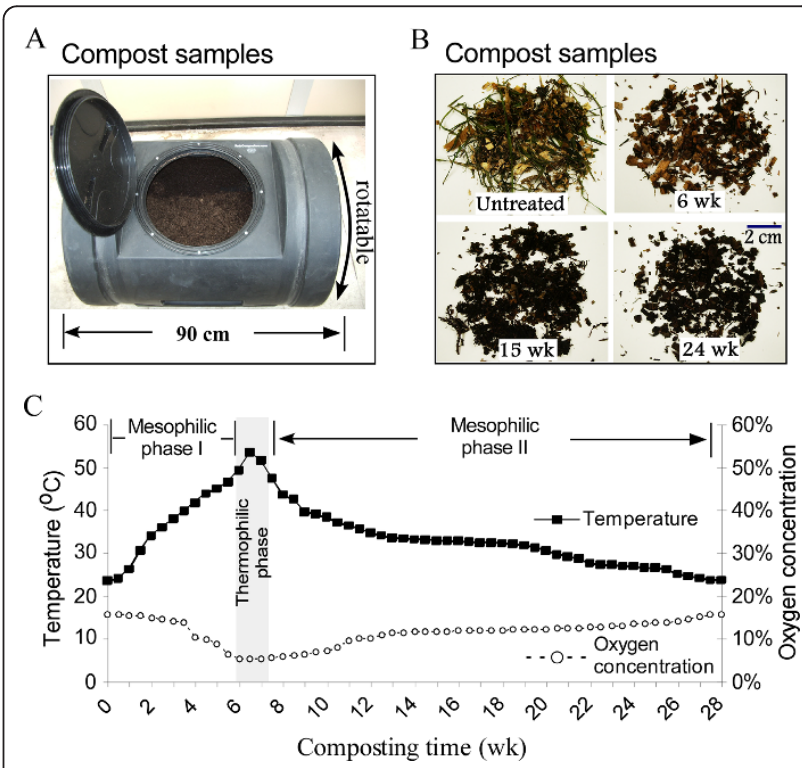

Figure 1 Compost setup and sampling. (A) The apparatus for composting of yellow poplar wood chips. (B) Representative samples collected showing morphological changes of composted poplar chips, i.e., size reduction, color darkening, and material softening. (C) Temperature and oxygen concentration measured, as described in Materials and Methods, during composting process. wk: week. 
Thereafter, the temperature returned to the mesophilic range until the composting finished.

Conventional composts usually contain highly nitrogenous materials, such as sewage and manures, in relatively large proportions, and thus tend to produce more heat and result in higher temperatures, up to $80^{\circ} \mathrm{C}$ [3], in the thermophilic phase. In contrast, our biomass compost contained less nitrogen and generated less heat, resulting in lower composting temperature.

The ambient oxygen concentration at the center of composter basically had a negative correlation with the compost temperature (Figure $1 \mathrm{C}$ ). When the temperature was at $50^{\circ}-53^{\circ} \mathrm{C}$ during the thermophilic phase, the ambient oxygen concentration reached levels as low as $4 \%$.

\section{Microscopic imaging reveals successive stages of deconstruction of composted biomass}

Biomass was imaged at successive stages of decay using optical microscopy. Apparent decay of the plant cell wall structure was observed after 6 weeks of composting (Figure 2). In the bright field (Figure 2, upper panel), the overall structure of the plant cell walls has begun to collapse at 15 weeks, and substantial biomass loss was observed at 24 weeks. In addition, a green-fluorescenceprotein tagged carbohydrate-binding module (CBM) was used as probe to localize cellulose, and labeled samples were then imaged with fluorescence microscopy. The family 3a CBM used in this study, termed CtCBM3, was originally isolated from Clostridium thermocellum scaffoldin protein, and has strong binding affinity to crystalline celluloses [17-20]. Figure 2 (lower panel) shows that the $C t C B M 3-G F P$ (green fluorescent protein) binding to yellow poplar cross-sections increased after 15 to 24 weeks of composting, suggesting that more hemicellulosic material was degraded in the early stages of composting, leading to progressively greater cellulose

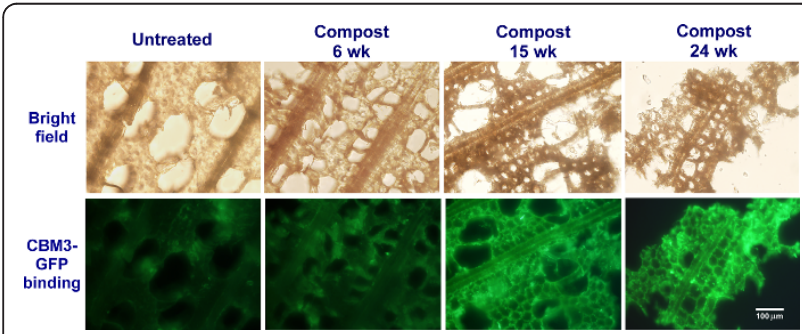

Figure 2 Cross-section micrographs of yellow poplar wood chips. (Top panel) Bright field microscopy shows composting effects on the cell wall structure over 24 weeks. (Bottom panel) fluorescence microcopy of the same field labeled by the CtCBM3GFP probe that binds to cellulose specifically. Increasing fluorescence intensity indicates higher cellulose accessibility to the probe. CtCBM3-GFP: family 3a carbohydrate-binding module tagged by green-fluorescent-protein. wk: week. exposure and increased access for the CtCBM3-GFP. Such observation is consistent with previous reports that removal of xylan enhances cellulose accessibility and digestibility [21].

\section{Compositional analysis for the composted materials}

To assess the degradation effect of composting on the feedstocks, the compost samples collected at 1 and 27 weeks were used to measure the remaining amounts of cellulose, hemicellulose and lignin, along with other compositions, using the chemical analysis procedures described in Materials and Methods.

The results are shown in Table 1 . Taking the data for week 1 samples as the "initial" numbers, we found that the cellulose content in compost samples changed from $39.2 \%$ to $19.5 \%$, i.e. decreased by $50 \%$. The contents of xylan and mannan, two major hemicellulose components, in compost samples changed from $13.9 \%$ to $7.1 \%$, and from $2.3 \%$ to $1.4 \%$, respectively. In other words, xylan and mannan decreased by $49 \%$ and $40 \%$, respectively. Taken together, these data indicate that the rates of the decrease in amounts of cellulose, xylan and acetyl groups (which mainly link with or exist in xylan) are very similar, between $47 \%$ and $50 \%$. This degradation effect is significant, and is comparable with the literature reported recalcitrance index (RI) value for hardwood biomass yellow poplar, which is 0.56 (means $44 \%$ of biomass is degradable; see the Discussion section).

Contrary to the trends seen for hemicellulose and cellulose contents, an increase in the content of lignin was observed (Table 1). This is likely a result of the absolute amount of lignin staying the same while the absolute amounts of other components decrease, rather than of the generation of lignin in composting. The percent by weight of structural protein increased as well, the much larger proportional change (more than 10-fold) in this case likely reflecting actual increases in absolute amounts of composting organisms and enzymes.

Future study of chemical compositional analysis at more sampling time points will be helpful to provide deeper insights into the composting process.

\section{rDNA shifts reflect environmental and microbial- population shifts}

Samples from 3, 6, 9, 15, 18, 24, and 27 weeks of composting were collected for total genomic DNA extraction. Figure 3A shows that the amounts of total genomic DNA increase steadily along the time course of composting with a peak at 18 weeks, followed by a decline in 24-27 weeks. This result appears to be correlated with the recorded drop in temperature during the late stages of composting (Figure 1C).

Like many other environmental samples, extracts from composted biomass materials may contain high 
Table 1 Compositional data for the composted materials

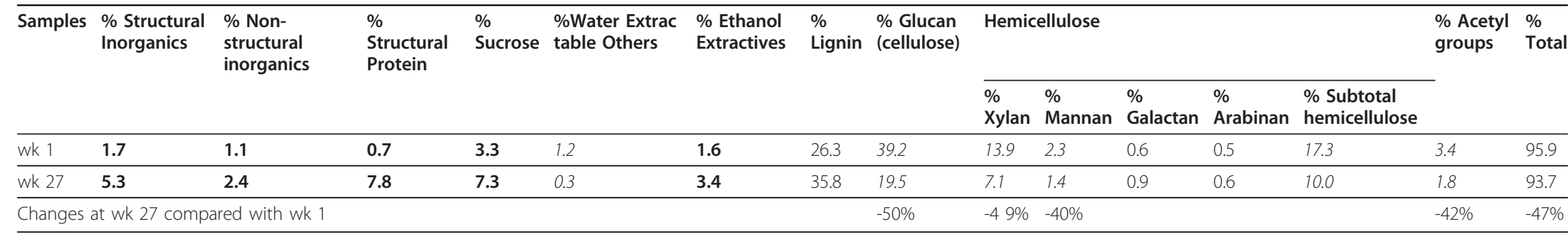

The data are averages of measurement of two replicate samples.

The bold numbers indicate the measurements that increase, while the italic numbers indicate the measurements that decrease during the composting process. wk, week 


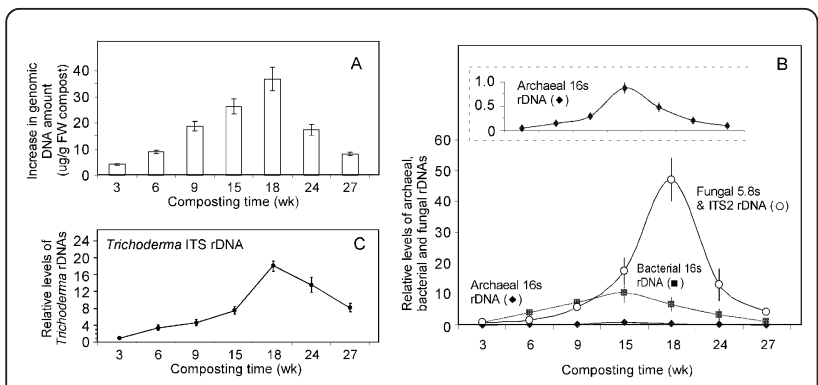

Figure 3 Relative abundance of total genomic DNAs extracted from composted yellow poplar chips, and microbial rDNAs by PCR using primers in Table 2 . Samples were collected in

composting time at 3, 6, 9, 15, 18, 24, and 27 weeks. (A) Amount of total genomic DNAs above the baseline genomic DNAs in compost at 1 week which was $32.7 \pm 2.6 \mu \mathrm{g} / \mathrm{g}$ FW compost (FW: fresh weight). (B) Relative level of bacterial, archaeal and fungal rDNAs. 16 $\mathrm{s}$ rDNA was used in bacteria and archaea, and $5.8 \mathrm{~s}$ and ITS2 rDNA were used in fungi. The bacterial rDNA abundance at 3 weeks was set as 1- fold; archaeal and fungal rDNA relative level was adjusted to bacterial rDNA abundance at 3 weeks. The insert in (B) shows the archaeal rDNA profiling with a fine scale for the relative levels of archaeal rDNA. Note the bacteria-dominant stage at 9 weeks, whereas the fungi-dominant and overall peak stage occurs at 18 weeks. (C) Relative levels of Trichoderma spp. ITS rDNA. Error bars indicate the standard errors of the mean (S.E. \pm mean) for the three replicates.

concentrations of organic matter. For example, humic acids commonly persist in isolated genomic DNA, and can be inhibitory to PCR and thereby compromise the quantitation of rDNA abundance. To address this issue, a serial dilution of isolated genomic DNA was tested to optimize the template concentration and to eliminate the effect of inhibitors. Using primers listed in Table 2, we found that genomic DNA concentrations between 0.08 and $2.5 \mathrm{ng}$ per well (20 $\mu$ l reaction volume) resulted in a linear relationship between Ct (cycle threshold, which is the main output of real-time PCR data, defined as the number of cycles required for the fluorescent signal to cross the threshold, i.e. exceed the background level) and the log of DNA concentration. The PCR amplification efficiency values, calculated as $10^{(-1 / \text { slope })}$ (in which the slope refers to the above-constructed $\mathrm{Ct}$ vs. the log of DNA concentration standard curve), were calculated to be $1.72,1.80$, and 1.81 for the archaeal, bacterial, and fungal rDNA primers, respectively. Note that a PCR amplification efficiency value of 2 means $100 \%$ success in PCR amplification. The obtained amplification efficiency values are comparable to those in other reports using the same or similar universal primers [22-24]. These values were used to calibrate the PCR-based measurement of rDNA abundance in this study.

To assess the diversity of each group of microbes at each stage of the composting, real-time PCRs were conducted using $2.5 \mathrm{ng}$ genomic DNA per reaction and universal primers for $16 \mathrm{~s}$ rDNA (bacteria and archaea) and $5.8 \mathrm{~s}$ and ITS2 rDNA (fungi) (Table 2). The archaeal, bacterial, and fungal rDNA relative abundance was first calculated with the delta-delta $\mathrm{Ct}$ method, using the bacterial rDNA level at 3 weeks as the common calibrator, and then normalized to the yield of total genomic DNA in each sample. The results are shown in Figure 3B. Interestingly, archaea and bacteria have similar patterns in rDNA abundance; both had a gradual increase with a peak at 15 weeks, followed by a decline until the end of composting. In contrast, fungi had a more distinctive pattern for rDNA abundance, which peaked at 18 weeks in a more abrupt rising and falling manner.

The observed higher proportion of fungi in the later stage of composting (Figure $3 \mathrm{~B}$ ) suggests that while bacteria may be more active when hemicelluloses are the easily accessible carbohydrates, fungi are more active when celluloses and lignins become exposed and accessible. The composting stages at week 9 and 18 therefore represent bacterial and fungal dominant phases, respectively (Figure 3B), and are candidate time points for sampling RNA for future metatranscriptomic analysis.

In addition, we also determined the relative abundance of Trichoderma spp. ITS rDNA during the time course of yellow poplar composting (Figure $3 \mathrm{C}$ ), as a measure of the presence and abundance of microorganisms of genus Trichoderma. This paves the way for the profiling of functional gene expression for representative species in this genus, as described in later section.

Table 2 Domain-level primers used to amplify short-subunit rDNA genes from DNA extracts of biomass compost

\begin{tabular}{llll}
\hline & Genes & Primer sequences \& reference & Amplicon size(bp) \\
\hline Archaea & 16 s rDNA & F: TTCCGGTTGATCCYGCCRG & 937 \\
& & R: YCCGGCGTTGAMTCCAATT \\
Ref: [22] & \\
\hline Bacteria & F: TCCTACGGGAGGCAGCAGT & 466 \\
& & R: GGACTACCAGGGTATCTAATCCTGTT & \\
\hline Fungi & 5.8 s and ITS2 rDNA & F: GCATCGATGAAGAACGCAGC & 400 \\
& & R: TCCTCCGCTTATTGATATGC & \\
& Ref: $[22,26]$ & \\
\hline
\end{tabular}


Table 3 Subgenus- and species-level primers used to determine the transcriptional levels of fungal cellulolytic genes in biomass compost

\begin{tabular}{|c|c|c|c|c|}
\hline Enzyme type/core species & $\begin{array}{l}\text { Target gene/ } \\
\text { enzyme }\end{array}$ & $\begin{array}{l}\text { Genbank accession No. or } \\
\text { reference }\end{array}$ & Primer sequences [l] & $\begin{array}{l}\text { Amplicon size } \\
\text { (bp) }\end{array}$ \\
\hline \multirow[t]{2}{*}{ Trichoderma spp. } & \multirow[t]{2}{*}{ ITS } & \multirow[t]{2}{*}{-} & F: TACCAAHCTGTTGCCTCGGCGG & \multirow[t]{2}{*}{$\sim 200$} \\
\hline & & & $\begin{array}{l}\text { R: } \\
\text { GATGAAGAAGGCAGCGAAATGCGATA }\end{array}$ & \\
\hline \multirow[t]{6}{*}{ Cellulase/Trichoderma spp. } & \multirow[t]{2}{*}{ cbh1/Cel7 A } & \multirow[t]{2}{*}[11]{} & F: GATGATTACTACGCCAACATGCTG & \multirow[t]{2}{*}{77} \\
\hline & & & R: ACGGCACCGGGTGTGG & \\
\hline & \multirow[t]{2}{*}{ eg/1/Cel7 B } & \multirow[t]{2}{*}[111]{} & F: CTGCAACGAGATGGATATCCTG & \multirow[t]{2}{*}{250} \\
\hline & & & R: GTGATGATGGTGAAGGTCTTGGAG & \\
\hline & \multirow[t]{2}{*}{$\mathrm{bg} / 1 / \mathrm{Cel} 3 \mathrm{~A}$} & \multirow[t]{2}{*}[\mathrm{IV}]{} & F: ATCAAGGTAGCTCAACATCGGG & \multirow[t]{2}{*}{124} \\
\hline & & & $\begin{array}{l}\text { R: } \\
\text { ACCTTATCTTGGAGATTGAGCTITGCC }\end{array}$ & \\
\hline \multirow[t]{2}{*}{ Hemicellulase/Trichoderma spp. } & \multirow[t]{2}{*}{$x y n 1$ and $x y n 2$} & \multirow[t]{2}{*}[\mathrm{V}]{} & F: CCGAGAAGTTGATGACCTTGTTC & \multirow[t]{2}{*}{87} \\
\hline & & & R: GGTCCAACTCGGGCAACTIT & \\
\hline \multirow{8}{*}{$\begin{array}{l}\text { Ligninase/Phanerochaete } \\
\text { chrysosporium }\end{array}$} & \multirow[t]{2}{*}{ LipA/B } & \multirow[t]{2}{*}{ M37701 } & F: ATCTCTGCCCACCCTGTCCT & \multirow[t]{2}{*}{256} \\
\hline & & & R: CTGAGCCAGCGAATGAGAGTC & \\
\hline & \multirow[t]{2}{*}{ LipD } & \multirow[t]{2}{*}{ M18743 } & F: CCCGGTCCTCGATGATATCC & \multirow[t]{2}{*}{201} \\
\hline & & & R: ATGTTCGGGTGGTACGTGGT & \\
\hline & \multirow[t]{2}{*}{$\mathrm{LipH}$} & \multirow[t]{2}{*}{ M24082 } & F: CGTCCACGGATATCGCTCTCT & \multirow[t]{2}{*}{102} \\
\hline & & & R: GCGAGGGAGACGCAAATTC & \\
\hline & \multirow[t]{2}{*}{ LipJ } & \multirow[t]{2}{*}{ AF140062 } & F: GCCGAGGCACATGAGTCTCTC & \multirow[t]{2}{*}{252} \\
\hline & & & R: TGTTCGGGTGGAAATTGGTC & \\
\hline
\end{tabular}

Note: the group primers targeting specific functional protein-encoding genes:

[I]. Orpinomyces spp. endo-1,4-glucanase gene: O. sp. PC-2, U97153; O. joyonii, AF015248.

[II]. Trichoderma spp. cellobiohydrolase I gene (cbh1): T. koningii, X69976; T. reesei, DD393553-DD393571; T. sp. FJ026620; T. viride, AY368686.

[III]. Trichoderma spp. endo- $\beta$-1,4-glucanase I gene (eg/1): T. longibrachiatum, X60652; T. reesei, AY928809; T. viride, AY343986

[IV]. Trichoderma spp. $\beta$-glucosidase 1 gene (bg/1): T. reesei, U09580; T. sp. SSL, FJ040193; T. viride, AY368687

[V]. Trichoderma spp. xyn1 and xyn2: T.reesei, X69573 (xyn1), U24191 (xyn2); T. harzianum, EU821597 (xyn2); T. pseudokoningii, EU360941 (xyn2).

In summary, the domain-level screening provided a strong timeline characterization for the composting process. The data from relative rDNA abundance for the microbial groups pointed to population shifts in the microbial composition during the composting process.

It is noteworthy that, in contrast to the dynamic changes in relative abundance of bacteria and fungi, archaea remain relatively stable in the amount of rDNA (1-2\%) throughout the course of the composting. Archaeal mass found in present yellow poplar compost is similar to that reported in other ecosystems, such as agricultural and field soils [27-29], suggesting as-yet-unknown roles for archaea in biomass decay systems.

\section{Functional gene expression profiling}

To deeply understand the dynamics of biomass composting, it is important to conduct functional expression profiling related specifically to the biomass-degrading process, namely of the known genes encoding cellulases, hemicellulases, and lignin-modification enzymes.
However, such functional studies are challenging because of the vast variety in the types of cell-walldegrading enzymes and the lack of experimentally-validated function annotations of related genes in public databases. As described above, the population dominance shifted from bacteria to fungi in later composting stage. We therefore focused on fungal genes. To this end, several model cellulolytic fungi for which genome sequences are available were selected for sequence alignment and primer design for RT-PCR of functional genes. Table 3 shows the list of primer sequences used for genes encoding cellulases, hemicellulases and $\beta$-glucosidases in the model aerobic fungus, Trichoderma spp., which is the dominant genus found in various biomass decay ecosystems, as well as being a common producer for most of the cellulase and hemicellulase enzymes used in industry), and for genes apparently encoding ligninase enzymes in the white-rot fungus Phanerochaete chrysosporium [30].

With the exception of those for Trichoderma sp. ITS rRNA [31], and $c b h 1 / \mathrm{Cel} 7 \mathrm{~A}$ and $b g l 1 / \mathrm{Cel} 3 \mathrm{~A}$ [adapted 
from literature [32]], and xyn 1 and $x y n 2$ of Trichoderma spp. [adapted from literature [33]], the primers employed were designed in this study.

Using the approaches described in the Materials and Methods section, expression levels of functional genes were calculated with the delta-delta $\mathrm{Ct}$ method, using Trichoderma spp. ITS (listed in Table 3) or fungal $5.8 \mathrm{~s}$ and ITS2 rDNA/rRNA (listed in Table 2) as an internal control for Trichoderma spp. and Phanerochaete chrysosporium genes, respectively. Each individual gene's mRNA level at 3 weeks was set as the reference value to calculate the subsequent fold changes.

(i) Transcription-level profiling of fungal hemicellulases and cellulases reflects coordination of gene expression in targeting progressively degrading biomass substrates

Trichoderma is a genus of fungi that exists, and often predominates, in broad types of soils and diverse environments including composts. Most species of this genus, including the industrial cellulase producer T. ree$s e i$, are saprophytes that can degrade bio-polymeric substrates such as lignocelluloses. This prompted us to use this genus as a model group to investigate the transcriptional dynamics of hemicellulase- and cellulase-encoding genes during the composting process.

To assess the relative expression levels of hemicellulases in composted samples, primers targeting both of the two major xylanases in Trichoderma (xyn 1 and $x y n 2$; Table 3) were used in real-time RT-PCR analysis. The results demonstrated that the expression levels for these xylanases steadily increased between 6 to 15 weeks of composting (Figure 4A), and then declined markedly after that.

Meanwhile, to assess the expression of cellulase genes of genus Trichoderma during the composting, three pairs of group primers listed in Table 3 were used for real-time RT-PCR. These primers correspond to three main categories of the Trichoderma cellulolytic enzyme systems that include cellobiohydrolase (CBH; exo-cellulases), endoglucanase (EGL; endo-cellulases) and beta-glucosidase (BGL). The gene expression profiling of the cellulases is shown in Figure 4B, with an increase between 6 to 18 weeks of composting, and a decrease thereafter. The expression patterns appeared to be similar among the tested genes during composting, an observation suggesting that these three types of cellulases may be expressed in a coordinated way that can enhance the overall efficiency of cellulose degradation.

Interestingly, as shown in Figure 4A-B, the gene expression of hemicellulases and cellulolytic system peaked at 15 and 18 weeks, respectively, suggesting that the microbial communities produce hemicellulases earlier than cellulases.

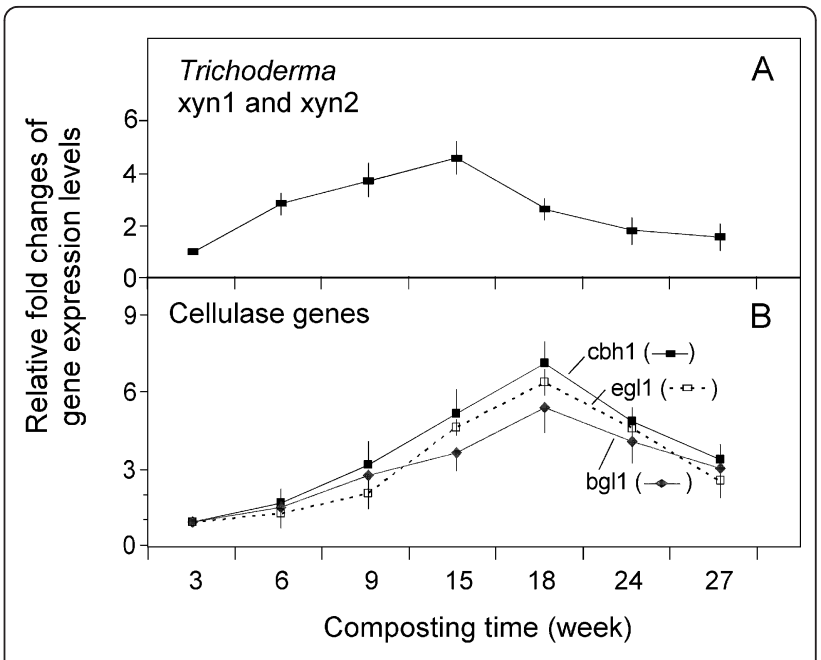

Figure 4 Transcriptional level of representative cellulolytic functional genes in Trichoderma sp. by real-time RT-PCR during composting of yellow poplar chips. (A) Xylanases 1 and 2 (xyn1 and xyn2). (B) Cellobiohydrolase I (cbh1), endoglucanase I (eg/1) and $\beta$-glucosidase $1(\mathrm{bg} / 1)$ were used in a set of representative species of Trichoderma genus. The gene expression level at each sampling time point of composting was first normalized with the Trichoderma sp. ITS rRNA, and then compared to their respective expression levels at 3 weeks (each of which was set as 1 fold). The primers for these genes were described in Table 3. Note that identical scales in the $X$ axis of panels $A-B$ allows a direct visual comparison of the magnitude of changes in gene expression levels.

(ii) Transcription-level profiling of fungal LiPs and MnPs Phanerochaete chrysosporium is a model fungus that can degrade lignin without "touching" the cellulose of the wood. Like other white rot fungi, P. chrysosporium secretes an array of peroxidases and oxidases that attack lignin [30,34]. We have successfully designed primers, as listed in Table 3, for the genes encoding manganese peroxidases (MnPs) and lignin peroxidases (LiPs). Real-time RT-PCR was used in determining their expression levels.

As shown in Figure 5A, the maximal fold changes of $M n P 1$ and $M n P 2$ were relatively small, in that the peak of $M n P 1$ expression was at 15 weeks with a 1.5 -fold increase (relative to the expression level at 3 weeks), while $M n P 2$ expression peaked later at 18 weeks with a larger (2.7-fold) increase. In contrast, the expression levels of the four LiP genes peaked at 18 weeks with more prominent changes than that of the $M n P$ genes (Figure 5B). Peaks are observed in the expression levels for LiPA/B and LiPD at 18 weeks, whereas the foldvalues for $L i P H$ and $L i P J$, while also maximal at 18 weeks, maintained quite high expression levels at 24 weeks, indicating a longer high plateau for their expressions.

In this study, we examined the expression patterns of a total of six $P$. chrysosporium genes at seven sampling 


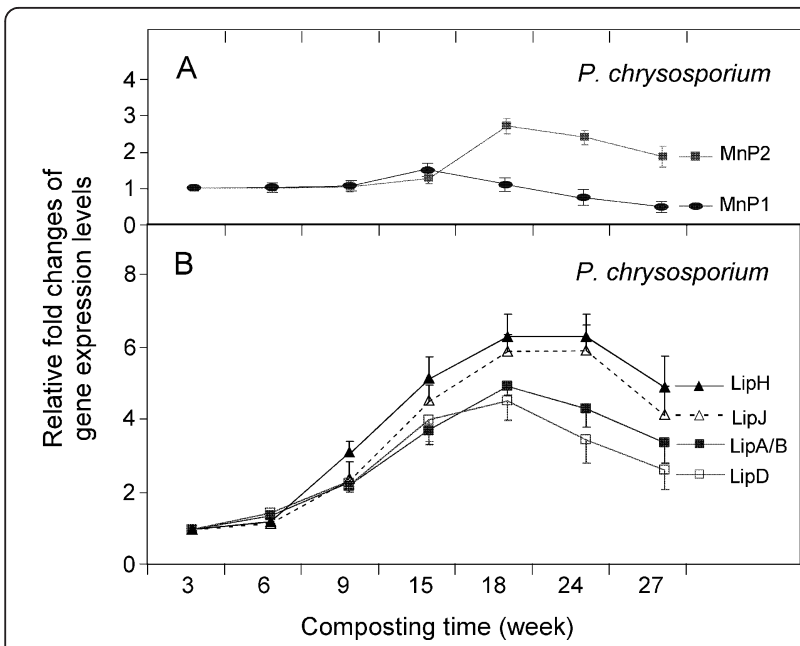

Figure 5 Transcriptional level of representative lignin degradation-related genes during the composting of yellow poplar chips. (A) Manganese peroxidase (MnP1 and MnP2). (B) Lignin peroxidase (LiP A/B, D, H and J). Gene sequences of fungus Phanerochaete chrysosporium were used to design primers for realtime RT-PCR. For each gene the expression level at each sampling time point of composting was compared to its expression level at 3 weeks (which was set as 1 fold).

time points (from 3 weeks to 24 weeks yellow poplar composting); we glean from the expression profiling data that the two $M n P$ genes are likely to be regulated differently, not only between themselves but also from the LiPs examined (Figure 5). This is in agreement with the findings by Janse et al. and Orth et al. who showed that $M n P 1-3$ genes are genetically unlinked to each other or to any LiP genes $[35,36]$.

\section{Hemicellulase and cellulase activities confirm microbial response to changes in chemical nature of exposed biomass surface}

In addition to examining the expression levels of functional genes, another approach to studying the function of a microbial community is to measure the actual activities of enzymes that we are interested in (i.e., glycoside hydrolases, specifically cellulolytic and hemicellulolytic enzymes, among others). We used low-molecularweight, soluble "model" substrates to assay activities in finely-ground samples of the total composted biomass materials, rather than in extracts. Our use of whole materials in the assays reflects our intention to conduct as comprehensive a survey as possible of the targeted glycoside hydrolase activities present in the composting material, including those activities tightly bound to the biomass as well as those readily extractable.

Using fluorogenic model substrates, we found that the cellulase activities show increasing predominance in later stages (24 weeks) of composting (Figure 6). In

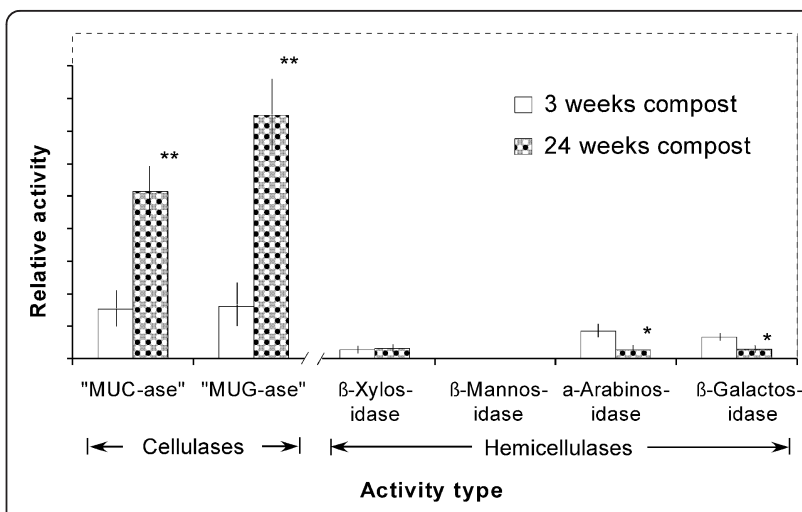

Figure 6 Total cellulase and hemicellulase activities agaist model substrates measured in composted yellow poplar, as a function of composting time. Activities are normalized to solids content of the compost sample and are averaged values from three replicates. Asterisks indicate statistically significant differences from the control (* for $p<0.05$; ** for $p<0.01$ ). Fluorogenic model substrates were used for the cellulase assay: MUC, 4methylumbelliferyl- $\beta$-D-cellobioside; MUG, 4-methylumbelliferyl- $\beta$-Dglucoside. Hemicellulase assays utilized the respective 4-

methylumbelliferyl- $\beta$-D-glycosides of the monosaccharides D-xylose, D-mannose, D-arabinose, and D-galactose.

contrast, the measured hemicellulase activities, mainly $\alpha$-arabinosidase and $\beta$-galactosidase, were higher in the earlier stages (3 weeks). These results are consistent with the light and fluorescence microscope observations that showed celluloses are exposed mainly at the later stages of composting. These parallel optical and enzyme-activity surveys provide direct evidence that local microbial populations adjust their production of "harvesting" enzymes in response to the accessibility and digestibility of chemically different biomass materials (going after the more accessible and digestible materials first) and indirectly suggest that the makeup of the microbial population itself may change in response to the changes in the chemical and physical nature of the biomass as degradation proceeds.

\section{Discussion}

Potential impact of a mixed compost feedstock on the microbial community

Literature has shown that there is a correlation between microbial species composition and the types of substrates in biomass-degrading microbial community [37]. Although the mixing ratio in fresh weight is $1: 1$ for the two feedstocks (yellow poplar chips and mown lawn clippings) used in setting up our composters, their mixing ratio in dry weight is 6:1 ( 85:15) after correction for the water content in each feedstock (listed in Table $4)$. Thus, yellow poplar is the major cellulolosic substrate based on its dry-weight contribution to the mixture. 
Table 4 The fresh weight (FW) and dry weight (DW) mixing ratios, and the estimated recalcitrance index (RI) for yellow poplar chips and mown lawn clippings using in setting up the compost of this study

\begin{tabular}{lllll}
\hline Compost feedstocks & FW mixing ratio & water $\%$ & DW mixing ratio & Estimated recalcitrance index * \\
\hline Yellow Poplar & 1 & $7 \%$ & 6 & 0.56 \\
\hline Mown lawn & 1 & $85 \%$ & 1 & 0.25 \\
\hline
\end{tabular}

Notes: *The RI value of yellow poplar chips is estimated to be 0.56 , an average for hardwood biomass, while that of mown lawn clippings is estimated to be 0.25 , a typical value for herbaceous plants such as corn stover and big bluestem grass biomass (see review [8]).

Furthermore, yellow poplar is much less degradable than mown lawn grass, with a recalcitrance index (RI) value twice that for the latter (Table 4). Taking these two considerations together, it is reasonable to conclude that the compost we characterized and presented here is dominated by yellow poplar substrate. In contrast, the impact of the minor feedstock, mown lawn grass, which accounts for only $15 \%$ of total dry feedstock in the setup of compost and is two times more easily degraded, is likely to be limited in determining the biochemical and microbial nature of the composting process, particularly in the later stages.

\section{Advantage and validity of using real-time PCR in analyzing transcriptional dynamics of composting}

The challenge in characterizing the microbial population is choosing the suitable approach(es) to target specific microorganisms, microbial groups, or their functional genes. In literature, real-time PCR is a highly sensitive method that has been successfully used to quantify not only the bacterial amount in complex communities [25,38-41], but also the functional genes present in soil [42] and in lower termite gut [43]. Such versatility of the real-time PCR approach prompted us to apply this technique to estimate the abundance of microbial rDNA and the transcriptional levels of their functional genes in genomic DNA and mRNA samples from compost, respectively.

It is noteworthy that most of the RT-PCR primers developed in the current study were designed against the sequences of functional genes from a set of representative lignocellulolytic microbial species within a specific genus such as Trichoderma (Table 3 and Figure 4). Based on the fact that Trichoderma spp. are often the most prevalent culturable fungi in soils [44], it is reasonable to speculate that Trichoderma spp. are likely to be also relatively abundant in our compost. Nevertheless, future study is needed to quantify what portion of the composting community is accounted for by the Trichoderma spp., using genus-specific ITS rDNA primers. Equally important, further study is also needed to explore whether other prominent fungal taxa display similar or different functional gene expression profiles as the composting proceeds.

It should also be noted that despite our efforts to optimize the genomic DNA extraction procedure, it might still be possible that certain microbial species (like some archaea and fungi) may be underestimated because of differing ease of lysis of different microbial species. However, this should not affect the validity of the data analysis, as all the samples collected from different time points were subjected to the same DNA extraction method. However, other factors, such as the extensive cell lysis that may occur in the late composting phase and cause biased low DNA extraction yield, may contribute to the observed total genomic DNA decline in 2427 weeks (Figure 3A).

\section{Correlative analysis in demystifying the composting process}

The advantage of conducting a comprehensive investigation of composting is that it allows us to depict a multifaceted picture of the structural, biochemical, and microbial dynamics involved in the natural degradation of yellow poplar wood chips. The combined use of a fluorescence labeling microscopic technique, cellulolytic enzyme assays, and real-time PCR allows us to make a correlative analysis. For example, the results showed that cellulase gene transcriptional levels peaked at 18 to 24 weeks of composting. In contrast, the transcriptional levels for surveyed hemicellulase genes peaked at around 15 weeks of composting. These results correlate well with the imaging data using GFP-tagged CBM as a molecular probe, which showed that the celluloses of yellow poplar biomass are mainly unwrapped and exposed at the later stage of composting (Figure 2), as well as with the enzymatic assay data, which showed the differential dominance of cellulase vs. hemicellulase in different stage of composting (Figure 6).

\section{Perspectives for biofuels production: lessons from} analysis of microbial communities in compost

Consolidated bioprocessing (CBP) is a promising concept that integrates enzyme production, enzymatic hydrolysis, and fermentation into a single process step, in which a single microorganism with both ethanologenic and cellulolytic functions, or a microbial consortium that combines these functions, is used, usually in one reactor [1]. Several CBP microorganisms such as Clostridium spp., Escherichia coli, Saccharomyces cerevisiae, and Bacillus subtilis have been proposed and used to implement this concept [see review [45]]. We 
previously proposed the approach of using a microbial consortium rather than a single microorganism in the actual development of CBP technology and suggested a compatibility approach between cross-feeding and sugar transport in optimizing CBP based on general analysis of natural paradigms in plant cell wall deconstruction [8].

Composting in the current study can be viewed as a natural variant of CBP in rotary composters that involves the interactions of microbes and their secreted enzymes with plant cell walls. Here, we propose to incorporate into the strategy for the development of CBP one observed attribute of woody biomass compost, which is the observed fungal dominance in the late phase of composting when more cellulose is exposed. Such observation is in line with the natural degradation of biomass in wood litter with a higher fungal contribution (67-99\%) to the total microbial mass (see review [8]). Because fungi have some types (families) of glycoside hydrolases (GHs), such as GH7 and GH61 [46,47], that bacteria lack, it is reasonable to speculate that the future CBP development may require transformation of fungi-unique GH genes and/or P. chrysosporium's ligninase genes into CBP strains (so far mainly bacteria and yeasts) in order to further enhance their lignocellulolytic functions.

As the examined representative fungal xylanases, cellulases and ligninases were differentially expressed at different composting stages in this study, the timing of adding or expressing such enzymes in a CBP should also be more precisely regulated according to the progress of lignocellulosic substrate degradation.

Solid-state fermentation (SSF) is a process wherein the growth of microorganisms takes place on a solid substrate in absence or near absence of free water, but with enough moisture to support microbial growth and metabolism [48]. It has been playing an important role in the biomass conversion research, reflected by the fact that SSF has been used to produce cellulases using T. reesei [49-51] and Penicillium janthinellum [52], to produce xylanase using B. subtilis ASH [37,53], B.licheniformis A99 [54] and Aspergillus tamarii [55], and to produce multiple cellulolytic enzymes in A. terreus M11, using various lignocellulosic materials as carbon source [56]. Composting of woody biomass can be viewed as an SSF, and our observations suggest that by monitoring the gene as well as protein expression of cellulases and xylanases at different stages of SSF, one may optimize the harvest timing for different enzymes, depending on the enzyme targets. Recently, semi-solid state fermentation (with higher water contents than SSF) of the oleagenic fungus Mortierella isabellina on the substrates of crusted freshly harvested sweet sorghum have been used to produce biodiesel [57]. As M. isabellina cannot utilize cellulose and xylan, it is reasonable to speculate that a co-culture with lignocellulolytic fungi such as $T$. reesei and $P$. chrysosporium may reduce the substrate cost by increasing the portion of useable materials in the substrate mixture.

\section{Conclusion}

To the best of our knowledge, this project constitutes the first comprehensive study of the natural composting of yellow poplar biomass. The following observations and implications highlight the value of using biomass compost for demystifying the enigma of "natural biomass conversion" in terms of lignocellulolytic gene expressions, enzymatic activities and their effects on deconstruction of plant biomass materials.

First, the CtCBM3-GFP fluorescence labeling experiments, enzymatic activity analyses and functional gene expression profiling suggest that more hemicelluloses were degraded in the early stages of composting and that the celluloses in the biomass were thereby progressively more "unwrapped" and exposed at the later stages.

Second, a significant microbial population shift observed in this study suggests that studies of the conditions at the transition points between bacteria- and fungus-dominated stages are critical for identifying new microbial systems that are potentially applicable to biomass conversion. Future metatranscriptomic analysis via mass-scale sequencing during these stages and at their transitions can provide great potential for discovering novel cellulolytic microbes and enzymes.

\section{Materials and methods \\ Apparatus and setup for biomass composting and sampling}

A drum-shaped rotary composter (Figure 1A) was set up in October 2007. The composter was loaded with a 1:1 by fresh-weight mixture of yellow poplar sawdust chips (collected from Sawmiller Inc., Haydenville, Ohio) and freshly-mown lawn grass clippings. As listed in Table 4, the dry-weight mixing ratio of yellow poplar chips and mown lawn grass clippings is $6: 1$. The lawn grass used was Kentucky Bluegrass (Poa pratensis L.) and the lawn was not fertilized in 2007 or during the preceding year. To inoculate the sample with microbes, composted material taken from a mixed, already-established natural compost pile of trimmed tree branches and twigs was added. Water was added to moisten the sample, and after the entire contents of the composter were mixed thoroughly, the initial moisture content of the mixture was determined by oven-drying of representative aliquots, to be approximately $58 \%$. The composter was rotated once a week, beginning on the $7^{\text {th }}$ day after the composter setup, in order to aerate the samples. At each of the designated sampling dates (i.e., 1, 3, 6, 9, 15, 
18,24 , and 27 weeks), the composted material was thoroughly mixed by rotating the composter bin and by stirring the materials inside with bars, both horizontally and vertically. After mixing, a total of about $200 \mathrm{~g}$ of compost was sampled from various depths below the compost mass surface and mixed. An aliquot was airdried and used to determine the water content, while the bulk of the withdrawn aliquot was stored at $-80^{\circ} \mathrm{C}$ for later use in bio-imaging, microbial rDNA and gene transcriptional profiling (for the samples collected at all the sampling time points), and enzyme-activity analyses (for the samples collected at week 3 and 18) as well as chemical compositional analysis (for the samples collected at week 1 and 27). The presented data are based on the studies of the compost samples from October 2007 compost samples. To test the reproducibility of the major measurements of this study, a second independent composting experiment was conducted in August 2009 following the same procedure as described above. The same sampling patterns and analyses were carried out for the second composting to track its microbial community composition (rDNA profiling) and cellulolytic gene expression, and the results obtained were consistent with the observation we made by using the samples from October 2007 compost (data not shown).

\section{Measurement of temperature and oxygen concentration}

Temperature and oxygen concentration were monitored constantly and recorded every other day during the composting process. Temperature at the center of the compost was measured using a 1522 Digital Indoor/ Outdoor Thermometer (Taylor Precision Products, Oak Brook, IL) and a Windrow Thermometer (REOTEMP Instrument, San Diego, CA); the oxygen concentration was measured using an oxygen analyzer (Model 630; Engineered Systems \& Designs, Newark, DE) at the center of the compost. To minimize the impact of the above-mentioned weekly (pre-sampling) rotation on the measurement of the temperature and oxygen concentration, these measurements were made before the scheduled rotation was conducted.

\section{Sample preparation for fluorescence microscopy}

The structural changes in plant biomass produced by the microbial decay community was assessed by both white-light and fluorescence microscopy. For sample preparation, small amounts of the frozen composted samples were immersed in water to thaw and soften the material. Single pieces of the composted biomass were then chosen and hand-cut in an orientation that would result in a transverse cross-sectioning. The thin sections were kept in water until being deposited onto a glass coverslips for microscopic analysis. Chemically-specific labeling of the composted material utilized a family-3 carbohydrate-binding module (CBM) fused with a green-fluorescent-protein tag, CtCBM3-GFP that was prepared in our previous work [20]. Labeling of the sectioned yellow poplar composted material with CtCBM3GFP was carried out in a blotting buffer $(50 \mathrm{mM}$ Tris, $\mathrm{pH}$ 8.0, $300 \mathrm{mM} \mathrm{NaCl}$ containing CtCBM3-GFP at a concentration of $0.1-0.3 \mu \mathrm{g} / \mu \mathrm{L}$ ) at room temperature for $30 \mathrm{~min}$. The sample was washed three times in washing buffer (50 mM Tris, pH 8.0, $300 \mathrm{mM} \mathrm{NaCl}$ ) followed by centrifugation $(1000 \times \mathrm{g}$ for $1 \mathrm{~min})$. The final pellet was transferred to a slightly different buffer (50 mM Tris, $\mathrm{pH} 7.0,20 \mathrm{mM} \mathrm{NaCl}$ ) and subjected to microscopic analysis. Samples including original, untreated material as control, and material sampled at 6, 15, and 24 weeks composting, were imaged using an Olympus inverted fluorescence microscope. Representative images were selected for display based on analysis of 10-14 microscopic fields from each of the examined compost samples.

\section{Composted material compositional analysis}

Compositional analysis of the composted materials was performed by using method described in the literature [58].

\section{Extraction of microbial genomic DNA and total fungal RNA from compost samples}

Total microbial genomic DNA was extracted from 5-g compost samples using the standard procedure provided by the Ultra Clean Mega Soil DNA Kit (MO BIO Laboratories, Carlsbad, CA). To increase the purity of extracted genomic DNA, a further purification of DNA samples was conducted using the Qiagen DNA Purification Kit (QIAGEN USA, Valencia, CA). The prepared DNA samples were quantified using a Nanodrop 1000 Micro-Volume UV-vis Spectrophotometer (Thermo Fisher Scientific, Inc., Waltham, MA) and stored at $-80^{\circ}$ $\mathrm{C}$ until used for the real-time PCR analysis using microbial rDNA primers, as described later.

The total fungal RNA of the compost was extracted from $1 \mathrm{~g}$ of each compost sample, which was ground to fine powder in liquid nitrogen using a mortar and pestle, followed by the extraction and purification protocol for filamentous fungi using Qiagen RNeasy Plant Mini Kit (QIAGEN USA, Valencia, CA). The above extracted total fungal RNAs were treated with DNase I (Invitrogen, Carlsbad, CA) to eliminate the genomic DNA contamination. One microgram of purified total RNA was reversetranscribed using SuperScript III Reverse Transcriptase with random primers (Invitrogen, Carlsbad, CA) according to the manufacturer's kit manual. The prepared fungal cDNA samples were stored at $-20^{\circ} \mathrm{C}$ until used for the real-time RT (reverse transcription) PCR amplification using functional gene primers, as described later. 
Real-time PCR using total genomic DNAs and real-time RT PCR using fungal cDNA

Real-time PCR, using the universal primer sets for archaeal, bacterial and fungal rDNA (Table 2) and the abovementioned extracted genomic DNAs as templates, was used for the detection and relative quantification of archaea, bacteria, and fungi in the composted materials. It is noteworthy that for archaea and bacteria, the three rRNA genes ( $5 \mathrm{~s}, 16 \mathrm{~s}$, and $23 \mathrm{~s}$ rDNA) typically exist as a co-transcribed operon. Similarly, fungi, like other eukaryotes, generally have many copies of the rRNA genes organized in tandem repeats; each repeat consists of the three genes encoding $5.8 \mathrm{~s}, 18 \mathrm{~s}$, and $28 \mathrm{~s}$ rRNA, in which genes are present as one transcription unit separated by two internally transcribed spacers (ITS). The sequences of $16 \mathrm{~s}$ rDNA for archaea and bacteria and $5.8 \mathrm{~s}$ rDNA for fungi are highly conserved and thus are commonly used for phylogenic characterization of populations.

In parallel, real-time RT (reverse transcription) PCR was employed to profile the selected genes encoding cellulolytic enzymes over the time course of composting, using the above prepared fungal cDNAs as templates and the primers designed as follows. The designing of the primers (Table 3 ) for these genes were based on the available gene sequences of representative fungal genera or species. Except for the primers for ligninase-encoding genes, which are based on single species of Phanerochaete chrysosporium, all other primers for cellulaseand hemicellulase-encoding genes were based on sequences from 2-4 different species of the same genus, and can therefore be viewed as group primers at the sub-genus level (Table 3). These sequences were then used to design the primers using the program Primer Express V.2 (Applied Biosystems, Foster City, CA) and specifying a $\mathrm{T}_{\mathrm{m}}$ value between $58^{\circ} \mathrm{C}$ and $62^{\circ} \mathrm{C}$ and an amplicon size between 100 and $250 \mathrm{bp}$.

PCR analyses were performed using the iCycler iQ real-time detection system (Bio-Rad, Hercules, CA). The iCycler iQ optical system software (version 3.0a; BioRad) was used to compile PCR protocols and set up the plate. Each microtiter plate well contained a $20-\mu \mathrm{L}$ mixture of the following: $10 \mu \mathrm{L} 1 \mathrm{X}$ iQ SYBR Green Supermix, which contained all the nucleotides, polymerase, reaction buffer, and SYBR green dye (Bio-Rad, Hercules, $\mathrm{CA}$ ), $5 \mu \mathrm{L}$ forward and reverse primers, giving final optimal concentrations of $300 \mathrm{nM}$ for each, and $5 \mu \mathrm{L}$ of DNA as template (2.5 ng per well). The PCR conditions for microbial rDNA amplification were described in the literature for the source of individual primers. For the primer pairs targeting functional genes listed in Table 3, amplification consisted of an initial hold at $95^{\circ} \mathrm{C}$ for 10 min followed by 40 cycles of $95^{\circ} \mathrm{C}$ for $15 \mathrm{~s}$ and $60^{\circ} \mathrm{C}$ for
60 s. All reactions were performed in triplicate and repeated in at least two independent experiments.

The PCR specificity for functional genes was confirmed at three levels. First, at the primer designing step, the designed primers were run through a Basic Local Alignment Search Tool (BLAST) search against the nucleotide collection (nr/nt) of NCBI. The designed primer should only hit only the target gene of the target species; any primer that matched sequences for organisms other than target species was abandoned. Second, at the end of real-time RT-PCR, the dissociation curve (i.e., melting curve) analysis of PCR end products was performed by ramping the temperature from $60^{\circ} \mathrm{C}$ to $95^{\circ} \mathrm{C}$ at a rate of $1^{\circ} \mathrm{C}$ per $30 \mathrm{~s}$; a PCR reaction with high specificity should have a single melting peak. Third, PCR products were analyzed by agarose gel electrophoresis to check for the presence of single band, with some PCR product bands being gel-purified using QIAquick spin columns (QIAGEN USA, Valencia, CA) and sequenced.

\section{Enzyme assay of cellulase and hemicellulase activities}

Approximately $5 \mathrm{~g}$ of frozen composted material was withdrawn from each of the representative samples at 3 weeks and 24 weeks into the composting process. Approximately $2.0 \mathrm{~g}$ of each sample was wet-ground with a mortar and pestle in $20 \mathrm{mM}$ sodium acetate buffer, $\mathrm{pH} 5.0$ at room temperature, then suspended in 20 $\mathrm{mL}$ of the same buffer to produce a uniform, readilypipettable slurry. The remainder of each frozen compost sample was weighed, oven-dried $\left(105^{\circ} \mathrm{C}\right.$, air), and reweighed to obtain a rough estimate of the biomass solids content of the slurry produced from that sample.

For the assay procedure, $0.8 \mathrm{~mL}$ of each well-mixed compost slurry was pipetted into each of three triplicate 2.0-mL HPLC vials. To each assay vial was added 0.2 $\mathrm{mL}$ of a $0.5-\mathrm{mM}$ solution of a given 4-methyl-umbelliferyl- $\beta$-D-glycoside substrate (cellobioside, glucoside, arabinofuranoside, xylopyranoside, galactoside, or mannopyranoside from Sigma-Aldrich, St. Louis, MO) in 20 $\mathrm{mM}$ sodium acetate buffer, $\mathrm{pH}$ 5.0. Each vial was crimpsealed, and the contents were mixed well by manual inversion before being incubated for 3 hours in a $30^{\circ} \mathrm{C}$ air incubator, with constant mixing by inversion at a rate of $10 / \mathrm{min}$. At the end of the 3 -h incubation, solids in the reaction mixtures were removed by centrifugation, and fluorescence of the cleavage product was developed by mixing $0.1 \mathrm{~mL}$ of each supernatant with $0.1 \mathrm{~mL}$ of $2 \mathrm{M} \mathrm{Na}_{2} \mathrm{CO}_{3}$ in one well of a 96-well, flatbottomed polystyrene plate (Evergreen Scientific, Los Angeles, CA). Product fluorescence was then read in a Tecan GENios plate reader (Tecan US, Chapel Hill, NC) with excitation/emission wavelengths at 340/465 nm. 
Relative enzyme activities were reported as raw fluorescence readings, minus the fluorescence of an identicallytreated blank with acetate buffer substituted for the biomass slurry.

\section{Abbreviations \\ BGL: Beta-glucosidase; CBH: Cellobiohydrolase; CBM: Carbohydrate-binding module; CBP: Consolidated bioprocessing; CtCBM3: Clostridium thermocellum carbohydrate-binding module 3; EGL: Endoglucanase; ITS: Internal transcribed spacer; LiP: Lignin peroxidase; MnP: Manganese peroxidase; PCR: Polymerase chain reaction; rDNA or rRNA: ribosomal DNA or RNA; XYN: Xylanase.}

\section{Acknowledgements}

This work was supported by the U.S. Department of Energy under Contract No. DE-AC36-08-GO28308 with the National Renewable Energy Laboratory (NREL), and was mainly funded by the Laboratory Directed Research \& Development (LDRD) program at NREL. Support from the DOE Office of Science, Office of Biological and Environmental Research through the BioEnergy Science Center (BESC), a DOE Bioenergy Research Center, for the imaging work, is gratefully acknowledged. We thank Dr. Yu-San Liu, Ms. PinChing Maness and Mr. Matthew Wecker for technical assistance, and David Templeton for compositional analysis of the composted materials. Thanks are also extended to Dr. Ze-Chun Yuan for critical review of the manuscript and helpful suggestions.

\section{Author details}

'Biosciences Center, National Renewable Energy Laboratory, Golden, CO 80401, USA. ${ }^{2}$ National Bioenergy Center, National Renewable Energy Laboratory, Golden, CO 80401, USA.

\section{Authors' contributions}

SYD, MPT and HW designed and coordinated the study, and revised the manuscript. HW, MPT and JOB conducted the compost setup and maintenance, sample harvesting, data analysis, and manuscript preparation. $H W, M H$ and $Y L$ conducted DNA and RNA extraction, primer selection and PCR reactions. HW and QX carried out fluorescence microscopy study of composted samples. Enzymatic activity assay was carried out by JOB. MEH was consulted. All authors read and approved the final manuscript.

\section{Competing interests}

The authors declare that they have no competing interests.

Received: 12 January 2012 Accepted: 10 April 2012

Published: 10 April 2012

\section{References}

1. Lynd LR, van Zyl WH, McBride JE, Laser M: Consolidated bioprocessing of cellulosic biomass: an update. Curr Opin Biotechnol 2005, 16:577-583.

2. Bayer EA, Lamed R, Himmel ME: The potential of cellulases and cellulosomes for cellulosic waste management. Curr Opin Biotechnol 2007, 18:237-245.

3. Ryckeboer J, Mergaert J, Vaes K, Klammer S, De Clercq D, Coosemans J, Insam $\mathrm{H}$, Swings J: A survey of bacteria and fungi occurring during composting and self-heating processes. Annals of Microbiology 2003, 53:349-410.

4. Wei H, Luo Y, Guo J, Yan L, Yang B, Zhang J, Hu Z, Sun L: Technological studies on production of biological-organic-inorganic compound fertilizer by utilizing the manure of livestock and poultry. Biotechnology 1999, 9:30-34

5. Wei H, Guo J, Zhou Q, Wang Z, Wu Z, Zhang J: Studies on biologicalorganic-inorganic fertilizer and its field application. Journal of Microbiology 1997, 17:18-24.

6. Allgaier M, Reddy A, Park J, Ivanova N, D'haeseleer P, Lowry S, Sapra R, Hazen T, Simmons B, VanderGheynst J: Targeted discovery of glycoside hydrolases from a switchgrass-adapted compost community. PLOS ONE 2010, 5:372-380

7. Li LL, Taghavi S, McCorkle SM, Zhang YB, Blewitt MG, Brunecky R, Adney WS, Himmel ME, Brumm P. Drinkwater C: Bioprospecting metagenomics of decaying wood: mining for new glycoside hydrolases. Biotechnology for Biofuels 2011, 4:23.

8. Wei H, Xu Q, Taylor L, Baker J, Tucker M, Ding S: Natural paradigms of plant cell wall degradation. Current Opinion in Biotechnology 2009, 20:330-338.

9. Foerstner K, Von Mering C, Hooper S, Bork P: Environments shape the nucleotide composition of genomes. EMBO reports 2005, 6:1208-1213.

10. Rio R, Lefevre C, Heddi A, Aksoy S: Comparative genomics of insectsymbiotic bacteria: influence of host environment on microbial genome composition. Applied and Environmental Microbiology 2003, 69:6825.

11. Hao Y, Winans SC, Glick BR, Charles TC: Identification and characterization of new LuxR/Luxl type quorum sensing systems from metagenomic libraries. Environmental Microbiology 2010, 12:105-117.

12. Michel FC, Marsh TJ, Reddy CA: Bacterial community structure during yard trimmings composting. Microbiology of Composting 2002, 25-42.

13. Ryckeboer J, Mergaert J, Coosemans J, Deprins K, Swings J: Microbiological aspects of biowaste during composting in a monitored compost bin. Journal of Applied Microbiology 2003, 94:127-137.

14. Talbot G, Roy CS, Topp E, Beaulieu C, Palin MF, Massé DI: Multivariate statistical analyses of rDNA and rRNA fingerprint data to differentiate microbial communities in swine manure. Fems Microbiology Ecology 2009, 70:540-552.

15. Dresboll DB, Magid J: Structural changes of plant residues during decomposition in a compost environment. Bioresource Technology 2006, 97:973-981.

16. Tringe S, Von Mering C, Kobayashi A, Salamov A, Chen K, Chang H, Podar M, Short J, Mathur E, Detter J: Comparative metagenomics of microbial communities. Science 2005, 308:554-557.

17. Tormo J, Lamed R, Chirino A, Morag E, Bayer E, Shoham Y, Steitz T: Crystal structure of a bacterial family-III cellulose-binding domain: a general mechanism for attachment to cellulose. The EMBO Journal 1996, 15:5739-5751.

18. Lacayo Cl, Malkin AJ, Holman HYN, Chen L, Ding SY, Hwang MS, Thelen MP: Imaging cell wall architecture in single Zinnia elegans tracheary elements. Plant Physiology 2010, 154:121-133.

19. Xu Q, Tucker MP, Arenkiel P, Ai X, Rumbles G, Sugiyama J, Himmel ME, Ding SY: Labeling the planar face of crystalline cellulose using quantum dots directed by type-I carbohydrate-binding modules. Cellulose 2009, 16:19-26.

20. Ding S, Xu Q, Ali M, Baker J, Bayer E, Barak Y, Lamed R, Sugiyama J, Rumbles G, Himmel M: Versatile derivatives of carbohydrate-binding modules for imaging of complex carbohydrates approaching the molecular level of resolution. Biotechniques 2006, 41:435-444.

21. Jeoh T, Ishizawa Cl, Davis MF, Himmel ME, Adney WS, Johnson DK: Cellulase digestibility of pretreated biomass is limited by cellulose accessibility. Biotechnology and Bioengineering 2007, 98:112-122.

22. Manerkar M, Seena S, Bärlocher F: Q-RT-PCR for assessing archaea, bacteria, and fungi during leaf decomposition in a stream. Microbial Ecology 2008, 56:467-473.

23. Fierer $\mathrm{N}$, Jackson JA, Vilgalys $\mathrm{R}$, Jackson RB: Assessment of soil microbial community structure by use of taxon-specific quantitative PCR assays. Applied and Environmental Microbiology 2005, 71:4117-4120

24. Kabir S, Rajendran N, Amemiya T, Itoh K: Quantitative measurement of fungal DNA extracted by three different methods using real-time polymerase chain reaction. Journal of Bioscience and Bioengineering 2003, 96:337-343.

25. Nadkarni $M$, Martin $F$, Jacques $N$, Hunter $N$ : Determination of bacterial load by real-time PCR using a broad-range (universal) probe and primers set. Microbiology 2002, 148:257-266

26. White TJ, Bruns T, Lee S, Taylor J: Amplification and direct sequencing of fungal ribosomal RNA genes for phylogenetics. In PCR Protocols, a Guide to Methods and Applications. Edited by: Ma I, Gelfand DH, Shinsky JJ, White TJ. New York: Academic Press; 1990:315-322.

27. Sandaa RA, Enger O, Torsvik V: Abundance and diversity of Archaea in heavy-metal-contaminated soils. Applied and Environmental Microbiology 1999, 65:3293-3297.

28. Buckley DH, Graber JR, Schmidt TM: Phylogenetic analysis of nonthermophilic members of the kingdom Crenarchaeota and their diversity and abundance in soils. Applied and Environmental Microbiology 1998, 64:4333-4339. 
29. Ochsenreiter T, Selezi D, Quaiser A, Bonch-Osmolovskaya L, Schleper C: Diversity and abundance of Crenarchaeota in terrestrial habitats studied by 16 S RNA surveys and real time PCR. Environmental Microbiology 2003, 5:787-797.

30. Bogan BW, Schoenike B, Lamar RT, Cullen D: Expression of lip genes during growth in soil and oxidation of anthracene by Phanerochaete chrysosporium. Applied and Environmental Microbiology 1996, 62:3697-3703.

31. Liu B, Glenn D, Buckley K: Trichoderma communities in soils from organic, sustainable, and conventional farms, and their relation with Southern blight of tomato. Soil Biology and Biochemistry 2008, 40:1124-1136.

32. Stricker AR, Grosstessner-Hain K, Wurleitner E, Mach RL: Xyr1 (xylanase regulator 1) regulates both the hydrolytic enzyme system and D-xylose metabolism in Hypocrea jecorina. Eukaryotic Cell 2006, 5:2128-2137.

33. Mach-Aigner AR, Pucher ME, Steiger MG, Bauer GE, Preis SJ, Mach RL: Transcriptional regulation of $x y r 1$, encoding the main regulator of the xylanolytic and cellulolytic enzyme system in Hypocrea jecorina. Applied and Environmental Microbiology 2008, 74:6554-6562.

34. Doddapaneni $H$, Yadav J: Microarray-based global differential expression profiling of P450 monooxygenases and regulatory proteins for signal transduction pathways in the white rot fungus Phanerochaete chrysosporium. Molecular Genetics and Genomics 2005, 274:454-466.

35. Orth AB, Rzhetskaya M, Cullen D, Tien M: Characterization of a CDNAencoding a manganese peroxidase from Phanerochaete chrysosporium Genomic organization of lignin and manganese peroxidase-encoding genes. Gene 1994, 148:161-165.

36. Janse B, Gaskell J, Akhtar M, Cullen D: Expression of Phanerochaete chrysosporium genes encoding lignin peroxidases, manganese peroxidases, and glyoxal oxidase in wood. Applied and Environmental Microbiology 1998, 64:3536-3538.

37. Gilbert GS, Gorospe J, Ryvarden L: Host and habitat preferences of polypore fungi in Micronesian tropical flooded forests. Mycological Research 2008, 112:674-680

38. McSweeney C, Denman S: Effect of sulfur supplements on cellulolytic rumen microorganisms and microbial protein synthesis in cattle fed a high fibre diet. Journal of Applied Microbiology 2007, 103:1757-1765.

39. Wanapat $M$, Cherdthong $A$ : Use of real-time PCR technique in studying rumen cellulolytic bacteria population as affected by level of roughage in swamp buffalo. Current Microbiology 2009, 58:294-299.

40. Mosoni P, Chaucheyras-Durand F, Béra-Maillet C, Forano E: Quantification by real-time PCR of cellulolytic bacteria in the rumen of sheep after supplementation of a forage diet with readily fermentable carbohydrates: effect of a yeast additive. Journal of Applied Microbiology 2007, 103:2676-2685.

41. Suzuki $M$, Taylor $L$, DeLong E: Quantitative analysis of small-subunit rRNA genes in mixed microbial populations via 5'-nuclease assays. Applied and Environmental Microbiology 2000, 66:4605-4614.

42. Sharma S, Radl V, Hai B, Kloos K, Fuka MM, Engel M, Schauss K, Schloter M: Quantification of functional genes from procaryotes in soil by PCR. Journal of Microbiological Methods 2007, 68:445-452.

43. Wheeler MM, Zhou XG, Scharf ME, Oi FM: Molecular and biochemical markers for monitoring dynamic shifts of cellulolytic protozoa in Reticulitermes flavipes. Insect Biochemistry and Molecular Biology 2007, 37:1366-1374.

44. Lorito M, Woo S, Harman G, Monte E: Translational research on Trichoderma: from'omics to the field. Annual Review of Phytopathology 2010, 48:395-417.

45. Zhang XZ, Zhang YHP: One step production of biocommodities from lignocellulosic biomass by recombinant cellulolytic Bacillus subtilis: Opportunities and challenges. Engineering in Life Sciences 2010, 10:398-406.

46. Harris P, Welner D, McFarland K, Re E, Poulsen J, Brown K, Salbo R, Ding H, Vlasenko E, Merino S: Stimulation of lignocellulosic biomass hydrolysis by proteins of glycoside hydrolase family 61 : Structure and function of a large, enigmatic family. Biochemistry 2010, 49:3305-3316.

47. Xu Q, Adney W, Ding S, Michael H: Cellulases For biomass conversion. In Industrial Enzymes: Structure, Function and Applications. Edited by: Polaina J, MacCabe A. New York: Springer; 2007:35-50.

48. Singhania RR, Patel AK, Soccol CR, Pandey A: Recent advances in solidstate fermentation. Biochemical Engineering Journal 2009, 44:13-18.

49. Latifian M, Hamidi-Esfahani Z, Barzegar M: Evaluation of culture conditions for cellulase production by two Trichoderma reesei mutants under solidstate fermentation conditions. Bioresource Technology 2007, 98:3634-3637.
50. Chahal D: Solid-state fermentation with Trichoderma reesei for cellulase production. Applied and Environmental Microbiology 1985, 49:205-210.

51. Xia L, Cen P: Cellulase production by solid state fermentation on lignocellulosic waste from the xylose industry. Process Biochemistry 1999, 34:909-912.

52. Adsul MG, Terwadkar AP, Varma AJ, Gokhale DV: Cellulases from Penicillium janthinellum mutants: Solid-state production and their stability in ionic liquids. Bioresources 2009, 4:1670-1681.

53. Battan B, Sharma J, Kuhad R: High-level xylanase production by alkaliphilic Bacillus pumilus ASH under solid-state fermentation. World Journal of Microbiology and Biotechnology 2006, 22:1281-1287.

54. Archana A, Satyanarayana T: Xylanase production by thermophilic Bacillus licheniformis A99 in solid-state fermentation. Enzyme and Microbial Technology 1997, 21:12-17.

55. Farani De Souza D, Giatti Marques De Souza C, Peralta RM: Effect of easily metabolizable sugars in the production of xylanase by Aspergillus tamarii in solid-state fermentation. Process Biochemistry 2001, 36:835-838.

56. Gao J, Weng H, Zhu D, Yuan M, Guan F, Xi Y: Production and characterization of cellulolytic enzymes from the thermoacidophilic fungal Aspergillus terreus M11 under solid-state cultivation of corn stover. Bioresource Technology 2008, 99:7623-7629.

57. Economou CN, Makri A, Aggelis G, Pavlou S, Vayenas D: Semi-solid state fermentation of sweet sorghum for the biotechnological production of single cell oil. Bioresource Technology 2010, 101:1385-1388.

58. Templeton DW, Scarlata CJ, Sluiter JB, Wolfrum EJ: Compositional analysis of lignocellulosic feedstocks. 2. Method uncertainties. Journal of Agricultural and Food Chemistry 2010, 58:9054-9062.

doi:10.1186/1754-6834-5-20

Cite this article as: Wei et al:: Tracking dynamics of plant biomass composting by changes in substrate structure, microbial community, and enzyme activity. Biotechnology for Biofuels 2012 5:20.

\section{Submit your next manuscript to BioMed Central and take full advantage of:}

- Convenient online submission

- Thorough peer review

- No space constraints or color figure charges

- Immediate publication on acceptance

- Inclusion in PubMed, CAS, Scopus and Google Scholar

- Research which is freely available for redistribution

Submit your manuscript at www.biomedcentral.com/submit
C) Biomed Central 